\title{
Behavioural Finance and Investment Preference in Private Equity Indian Companies
}

\author{
Chabi Gupta, Rachna Saxena
}

\begin{abstract}
At first glance, it may be easy to see many deficiencies in the efficient market theory, created in the 1970s by Eugene Fama. Eugene Fama never imagined that his efficient market would be $100 \%$ efficient all the time. Of course, it's impossible for the market to attain full efficiency all the time, as it takes time for stock prices to respond to new information released into the investment community. The efficient hypothesis, however, does not give a strict definition of how much time prices need to revert to fair value. Moreover, under an efficient market, random events are entirely acceptable but will always be ironed out as prices revert to the norm.

It is important to ask, however, whether EMH undermines itself in its allowance for random occurrences or environmental eventualities. There is no doubt that such eventualities must be considered under market efficiency but, by definition, true efficiency accounts for those factors immediately. In other words, prices should respond nearly instantaneously with the release of new information that can be expected to affect a stock's investment characteristics. So, if the EMH allows for inefficiencies, it may have to admit that absolute market efficiency is impossible
\end{abstract}

The study tries to elucidate the very factor that is "Cognitive psychology: the study of how people (including investors) think, reason, and make decisions". They may not be always rational. Individuals do not always act shrewdly when it comes to making financial decisions and that there are various mental errors that influence them while making decisions. The sample size of the study is 60 employees of private equity companies. The sampling technique used is simple random sampling. Primary data has been used in the study, which was collected through a structured questionnaire based on behavioral finance techniques and investment preference. Various statistical tools were used to analyze the data like Descriptive Statistics, t-Test Statistical Tool, Correlation Tool and Percentage Analysis. The study tried to explain the irrational decisions taken by the investors during the time of taking financial portfolio decisions. Through the study, it is discerned that private equity employees are aware about the various possibilities in investments and it is found that there exist a relationship between behavioral finance and investment preference among employees of private equity companies. Using the principles of behavioral finance and investment preference the study tried to delve the psychological concept of “individual attachment style", especially with reference to employees of private equity companies and the wide range of investment avenues and their investment preference procedure.

\footnotetext{
Revised Manuscript Received on September 25, 2019

* Correspondence Author

Dr Chabi Gupta, Professor, New Delhi Institute of Management, India.

Dr Rachna Saxena, Associate Professor, New Delhi Institute of Management, India
}

Keywords : Behavioral Finance, Investment Preferences, Cognitive Biases, Individual Decision Making, Rational Investor.

\section{INTRODUCTION}

The author of this dissertation chose the topic of behavioral finance theories for the reason of studying the controversial relevance of these theories in relation to investment strategies. Reading investment books and newspaper articles has been a part of the writers' daily life for many years. Hence, the writer's interest towards investment strategies and behavioral finance theories has grown over time. Behavioral theories are viewed as a relatively new phenomenon in the security markets. Therefore, examining the subject is essential in order to understand the changing world of investments. In today's world investing in stocks and funds is made easy. Investors do not need any specific education or knowledge to purchase stocks. Current technology enhances fast trade between individual investors. The concept of investing is seen as trendy. Therefore, people tend to make illogical decisions not based on true knowledge or information of a certain investment object.

This research study examines the relationship between behavioral finance and investment preferences of the employees of private equity companies in India.

\section{SIGNIFICANCE OF THIS RESEARCH}

The behavioral finance has emerged due to the financial difficulties faced in the traditional setup. Behavioral finance seeks to find how investor's emotions and psychology affect investment decisions. The study is conducted to analyze how effectively the behavioral factors and investment preferences factors influencing the employees of private equity companies who make common mental errors in financial decision making for their investments.

The behavioral factors include cognitive biases which influences the decision making and decision outcomes, prospective factors which includes representativeness, overconfidence, anchoring problem and availability biases. The prospective factors, 
which affect the behavior of investor such as loss aversion and regret aversion. The investor should have a clear idea about when to invest in the market. Another common behavioral bias is the herding effect in which an investor makes informed decisions depending on recommendations from other relatives or investors. The portfolio investors take decisions where there is a chance of incurring losses in the future. The investor should be capable of taking a well-informed decision, which will be prospective to him.

These decisions are explained via several behavioral finance theories. The outcome of poor knowledge is that investors allow these theories to effect on their decision-making process, thus resulting in major losses. The behavioral models can effect on individuals' decision-making whether actual investments are conducted via professionals or not. The concept of investing is extensive as it can include all the aspects of purchasing items expected to gain more value in the future (art, antique, securities etc.). Therefore, it has decided to narrow down the subject to concentrate on stock trading and the impact of behavioral finance on individual portfolio investors. Thus the researcher here in this study is interested in the relationship between behavioral finance and investment preferences among employees of private equity companies.

\section{LITERATURE REVIEW}

Renu and Christie (2018) conducted a theoretical study on "A Behavioral Finance Perspective of the Stock Market Anomalies". The research mainly explained the idea of behavioral finance, prospect theory, and classical financial theory and the inconsistency in the stock market from the behavioral finance aspect. Only secondary data was collected for this study. The research summarized various problems like behavioural biases that lead to the abnormal behavior of the stock market that was left unexplained by scholastic financial theories.

Shunmuga (2017) conducted a study on "Behavioral finance a study with reference to the small individual investors in Tirunelveli city". The primary objective of the study was to identify the impact level of behavioral factors on the investment decisions and performance of the employees of private equity companies. The study was a sample survey. Sample size for the study was 384 out of total population of the Tirunelveli city. The sampling technic used was probability sampling. The statistical tool used for the analysis was chi square test analysis. The finding of the study was that there was a high impact of behavioral aspect on the investment choices and performance of the employees of private equity companies.

Yamini (2016) conducted a study on "Behavioral finance a study on investors behavior towards equity market investments with reference to investors of Delhi". The main objective of the study was to identify the various behavioral biases affecting the decision-making process of investors and to analyze investors attitude towards various equity market investment. The study was a sample survey. The sample size was 5000. $10 \%$ of 5000 samples, i.e. 500 samples were picked randomly and after ignoring the incomplete questionnaires, 380 samples were used for the analysis. The sampling technic used was random sampling. The statistical tool used for the study was discriminant function analysis and weighted scoring method. The finding of the study was that the investors are not familiar with the concept of behavioral finance and the investors are not much familiar with the equity market instrument to make investment decisions.

Parimalakanthi and Ashok (2015) conducted a study on "A study on investment preference and behavior of individual investors in Coimbatore city". The main objective of the study was to study the investment preference and behavior of individual investors of Coimbatore city. The sample size was 107. The sampling technic used was convenient sampling. The statistical tool used for the study was friedman test, garratt ranking and factor analysis. The major finding of the study was that investors before making the investment should need to collect investment related information from the internet and consult with friends and investment experts before investing. The outcome of this study was that the most of the investors prefers bank deposits followed by gold and silver investment.

Kajal (2015) conducted a study on "Investment preferences of investors- a survey Chennai". The objective of this study was to assess incidence of retail participation in thestock market in Chennai. The sample size for the study was 200. The sampling technique used was stratified sampling. The statistical tool used for the study was chi-square test. The findings of the study was that most of the retail investors find the stock market activities too complex and difficult to comprehend. The main reason behind the ignorance respondents in stock market investing was fear of losing money.

Joseph and Prakash (2014) conducted a study on "A study on investment avenues among the people and factors 
considered for investment". The main objective of this study was to understand and analyze the present investment avenues among the people and the factors considered for making an investment. The sample size of the study was 100 who are a part of working population in Bangalore city. The sampling technic used was convenient sampling method. The findings of the study was that the all age group of respondents give more importance to invest in insurance and bank deposit and it is found that income level of a respondent is an important factor which affects the investment pattern of the respondent.

Behavioral finance, a study of the market that draws on psychology, throws light on why people buy or sell stocks and why sometimes do not buy or sell at all. The most crucial challenge faced by the investor is in investment decisions. The profit made, or losses incurred by an investor can be attributed mainly to his decision-making abilities. The fact that even the most prominent and well-educated investors were affected by the collapse of the speculative bubble in the 2008 subprime crisis proved that something was fundamentally missing in the traditional models of rational market behavior. In this study, the aim is to establish the existence of such fundamental issues, driven by various psychological biases, in the investment decision-making process.

\section{OBJECTIVES OF THIS RESEARCH}

1. To find the level and existence of behavioral biases among employees of private equity companies.

2. To find the level of investment performance among employees of private equity companies.

3. To find if there is a significant difference between

behavioral biases based on age, education level and monthly income.

4. To find if there is a significant difference between investment preferences based on age, education level and monthly income.

5. To find the correlation between behavioral finance and investment preference.

\section{FORMULATION OF HYPOTHESIS}

1. There exists a high level of behavioral biases among employees of private equity companies.

2. There exists a high level of investment preferences among employees of private equity companies.

3. There exists a significant difference in behavioral biases based on gender, occupation and monthly income.

4. There exists a significant difference in investment preferences based on gender, occupation and monthly income.

5. There exists a significant difference in correlation between behavioral finance and investment preferences

The present study has been conducted with both primary as well as secondary data. Primary data collection has been done

using structured questionnaire consisting of different questions on various aspects, which is collected from employees of private equity companies. Secondary data collection has been done through different types of research conducted related to the topic, well-known articles and journals.

\section{TOOLS USED}

Attitude Scale of Behavioral Finance

A Likert type scale was prepared which has 5 points were each point valued as mentioned below;

"5 - Strongly Agree, 4 - Agree, 3 - Neutral, 2 - Disagree, 1 Strongly Disagree".

The components of scale include heuristic factors, prospective factors, market factors and herding effects of an investor.

Attitude Scale of Investment Preferences

A Likert type scale was prepared which has 5 points were each point valued as mentioned below;

"5 - Strongly Agree, 4 - Agree, 3 - Neutral, 2 - Disagree, 1 Strongly Disagree".

The components of scale include financial literacy of an investor, total money to be invested, risk taking ability and investment objectives of an investor.

\section{Sampling Techniques}

The sample size of the study is 60, a structured questionnaire has been distributed amongst the sample. Simple random sampling technique was the sampling technic used for data collection.

Only private equity companies have been considered for the purpose of sampling.

Statistical Tools Used

- Descriptive Statistical Tool

- T-Test Statistical Tool

- Correlation

- Percentage Analysis

\section{ANALYSIS AND INTERPRETATION}

To find out the level of Behavioral Biases among employees of private equity companies.

A grading table has been made to assess the level of behavioral finance. If the mean score ranges between (1-33) rated as low level, (34-66) rated as moderate level and (67-100) as high level.

Table 1 Level of Behavioral Biases among employees of private equity companies in Descriptive Statistics

\begin{tabular}{|l|l|}
\hline Descriptive Statistics & Level \\
\hline Mean & 86.19 \\
\hline Median & 88.00 \\
\hline Mode & 89.00 \\
\hline Standard Deviation & 6.677 \\
\hline
\end{tabular}

Table 1 shows that the mean value is 86.19 with a standard deviation of 6.677 .

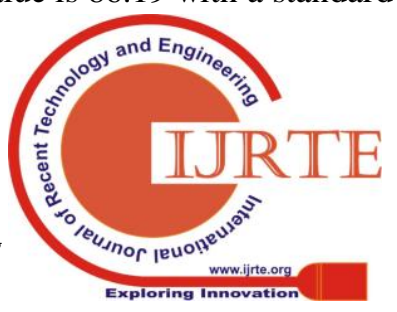


According to the grading table, there exist a high level of behavioral biases among employees of private equity companies.

To find out the level of Investment Preference among employees of private equity companies.

A grading table is been made to assess the level of investment preference. If the mean score ranges between (1-33) rated as low level, (34-66) rated as moderate level and (67-100) as high level.
Table 2 Level of Investment Preference among employees of private equity companies Descriptive Statistics

\begin{tabular}{|l|c|}
\hline \multicolumn{1}{|c|}{$\begin{array}{c}\text { Descriptive } \\
\text { Statistics }\end{array}$} & Level \\
\hline Mean & 74.09 \\
\hline Median & 76.00 \\
\hline Mode & 79.00 \\
\hline Standard Deviation & 6.521 \\
\hline
\end{tabular}

Table 2 shows that the mean value is 74.09 with a standard deviation of 6.521. According to the grading table, there exist a high level of behavioral finance among employees of private equity companies.

To find out the significant difference of Behavioral Finance based on gender, occupation and monthly income.

Table 3 Behavioral biases based on Gender.

\begin{tabular}{|c|c|c|l|r|r|}
\hline Gender & Frequency & Mean & $\begin{array}{l}\text { Standard } \\
\text { Deviation }\end{array}$ & t-value & p-value \\
\hline Male & 49 & 89.16 & 2.728 & \multirow{2}{*}{16.749} & 0.000 \\
\cline { 1 - 4 } Female & 11 & 74.00 & 3.181 & & \\
\hline
\end{tabular}

Table 3 shows the data relating to gender wise analysis on behavioral finance of employees of private equity companies. Here the p-value is 0.000 , which shows that there exists a significant difference in behavioral biases among employees of private equity companies.

Table 4 Behavioral finance based on occupation

\begin{tabular}{|c|c|c|c|c|c|}
\hline Occupation & Frequency & Mean & $\begin{array}{c}\text { Standard } \\
\text { Deviation }\end{array}$ & t-value & p-value \\
\hline Public & 52 & 85.61 & 7.202 & -1.334 & 0.191 \\
\hline Private & 8 & 88.99 & 2.038 & & \\
\hline
\end{tabular}

Table 4 shows the data relating to occupation wise analysis on behavioral finance of employees of private equity companies. Here the p-value is 0.191 , which shows that there does not exist a significant difference in behavioral biases among employees of private equity companies.

Table 5 Behavioral finance based on monthly income

\begin{tabular}{|c|c|c|c|c|c|}
\hline $\begin{array}{c}\text { Monthly } \\
\text { Income }\end{array}$ & Frequency & Mean & $\begin{array}{c}\text { Standard } \\
\text { Deviation }\end{array}$ & t-value & p-value \\
\hline Below 40000 & 50 & 85.95 & 6.773 & -0.594 & 0.544 \\
\hline Above 40000 & 10 & 87.26 & 6.482 & & \\
\hline
\end{tabular}

Table 5 shows the data relating to monthly income wise analysis on behavioral finance of employees of private equity companies. Here the p-value is 0.544 , which shows that there does not exist a significant difference in behavioral biases among employees of private equity companies.
To find out the significant difference of Investment Preference based on gender, occupation and monthly income

Table 6 Investment Preference based on Gender.

\begin{tabular}{|c|c|c|c|c|c|}
\hline Gender & Frequency & Mean & $\begin{array}{c}\text { Standard } \\
\text { Deviation }\end{array}$ & t-value & p-value \\
\hline Male & 49 & 75.27 & 6.016 & 3.002 & 0.05 \\
\hline Female & 11 & 69.33 & 6.655 & & \\
\hline
\end{tabular}

Table 6 shows the data relating to gender wise analysis on investment preference of employees of private equity companies. Here the p-value is 0.05 , which shows that there exists a significant difference at 0.05 level of significance among employees of private equity companies. 
Table 7 Investment preference based on occupation

\begin{tabular}{|c|c|c|c|c|c|}
\hline Occupation & Frequency & Mean & $\begin{array}{c}\text { Standard } \\
\text { Deviation }\end{array}$ & t-value & p-value \\
\hline Public & 52 & 75.47 & 5.782 & 4.514 & 0.000 \\
\hline Private & 8 & 66.23 & 4.994 & & \\
\hline
\end{tabular}

Table 7 shows the data relating to occupation wise analysis on investment preference of employees of private equity companies. Here the p-value is 0.000 , which shows that there exists a significant difference in investment preference among employees of private equity companies.

Table 8 Behavioral biases based on monthly income

\begin{tabular}{|c|c|c|c|c|c|}
\hline $\begin{array}{c}\text { Monthly } \\
\text { Income }\end{array}$ & Frequency & Mean & $\begin{array}{c}\text { Standard } \\
\text { Deviation }\end{array}$ & t-value & p-value \\
\hline Below 40000 & 50 & 74.44 & 6.450 & 0.879 & 0.388 \\
\hline Above 40000 & 11 & 72.55 & 6.991 & & \\
\hline
\end{tabular}

Table 8 shows the data relating to monthly income wise analysis on investment preference of employees of private equity companies.

Here the p-value is 0.388 , which shows that there does not exist a significant difference in investment preference among employees of private equity companies.

Table 9 Correlation of Behavioral finance and Investment preference

\begin{tabular}{|l|l|c|c|}
\hline \multicolumn{2}{|c|}{ Ccale } & Investment Preference & Behavioral Finance \\
\hline \multirow{3}{*}{ Investment Preference } & Pearson Correlation & 1 & .478 \\
\cline { 2 - 4 } & p-value & & 0.000 \\
\cline { 2 - 4 } & $\mathrm{N}$ & 60 & 60 \\
\hline \multirow{3}{*}{ Behavioral finance } & Pearson Correlation & .478 & 1 \\
\cline { 2 - 4 } & p-value & 0.000 & 60 \\
\cline { 2 - 4 } & $\mathrm{N}$ & 60 & 6 \\
\hline
\end{tabular}

Table 9 shows the correlation between Behavioral finance and Investment preference. . The table shows that there exists a positive correlation among the behavioral finance and
To find out the correlation between behavioral finance and investment preference among employees of private equity companies. investment preference among employees of private equity companies.

Table 10 Percentage analysis of most preferred Investment Avenues

\begin{tabular}{|l|c|c|}
\hline \multicolumn{1}{|c|}{ Investment avenues } & No. of respondents & Percentage (\%) \\
\hline Shares & 8 & 13 \\
\hline Debentures/Bonds & 3 & 8 \\
\hline Mutual Funds & 16 & 2 \\
\hline NSC/Provident funds & 1 & 17 \\
\hline Fixed Deposits & 10 & 10 \\
\hline Insurance policies & 12 & 26 \\
\hline Real Estate & 6 & 7 \\
\hline Gold/Silver & 3 & 0 \\
\hline Other investment avenues & 0 & 100 \\
\hline Total & 60 & \\
\hline
\end{tabular}

Table 10 shows the percentage analysis of most preferred investment avenues of employees of private equity companies. Out of 60 respondents, $26 \%$ respondents prefer real estate as the most preferred investment avenue, which is highest among all other investment avenues. Then comes the mutual fund, which has $19 \%$ respondents. $17 \%$ respondents prefer fixed deposits as most preferred investment avenue. $13 \%$ respondents prefer shares as most preferred investment avenue. $10 \%$ respondents prefer insurance policy as most preferred investment avenue. $7 \%$ respondents prefer both gold /silver and debentures/bonds as most preferred Investment Avenue and none of the respondents prefers other investments than above mentioned.

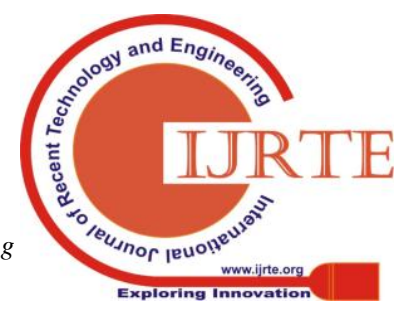




\section{FINDINGS OF THE RESEARCH}

- It is found that there is a high level of behavioral biases and investment preferences among employees of private equity companies.

- There exists a significant difference in behavioral biases based on gender.

- There does not exist a significant difference behavioral biases based on occupation and monthly income of employees of private equity companies.

- There exists a significant difference in investment preferences based on gender and occupation.

- There does not exist a significant difference in investment preferences based on monthly income.

- There exists a significant difference in correlation between behavioral finance and investment preferences among employees of private equity companies.

- It is found that real estate, mutual fund and fixed deposits are the most preferred investment avenue among employees of private equity companies.

- First hypothesis is fully accepted.

- Second hypothesis is fully accepted.

- Third hypothesis is rejected because there exists a significant difference only in gender.

- Fourth hypothesis is partially accepted.

- Fifth hypothesis is fully accepted.

\section{CONCLUSION}

An integral study of Behavioral finance explains why employees of private equity companies make irrational decisions. It also shows how factors influence the employees of private equity companies while making portfolio decisions regarding investments. One of the pertinent factor dependent behavioral finance is preferring the investments. Proper awareness programs should be conducted for the employees of private equity companies in order to reduce cognitive biases during portfolio investment decision making. By taking good and timely decisions and diversifying the portfolios properly then these employees of private equity companies can satisfy their financial, social and psychological needs in the long run.

\section{REFERENCES}

1. Shleifer, Andrei. 2000. Inefficient Markets: An introduction to Behavioral Finance. New York: Oxford University Press.

2. Sinha, Anand.2012. Changing Contours of Global Crisis - Impact on Indian Economy.

http://rbi.org.in/scripts/BS_SpeechesView.aspx?Id=678> . Retrieved: April 2012 Sons.

3. Selden, G. C., 1965. Psychology of the Stock Market

4. Shefrin, Hersh (Editor), 2001. Behavioral Finance

5. Shefrin, Hersh, 2000. Beyond Greed and Fear : Understanding Behavioral Finance and the Psychology of Investing.

6. Shiller, Robert J., 2000, 2006. Irrational Exuberance.

7. Nofsinger, John R., 2001. Investment Madness : How Psychology Affects Your Investing--and What to Do About It,

8. Nofsinger, John R.2001. Investment madness: how psychology affects your investing - and what to do about it. USA: Pearson Education

9. Nunnally, C. J. 1976. Psychometric Theory, New York: McGraw Hill

10. O'Hagan, Anthony.,Buck, Caitlin E., Daneshkhah, Alireza., Eiser, J Richard.,Garthwaithe, Paul H., Jenkinson, David J,. Oakley, Jeremy E., and Rakow, Tim.2006.Uncertain Judgements: Eliciting Experts' Probabilities. USA: John Wiley \& Sons.

11. Odean, Terrance. 1998. Volume, Volatility, Price, and Profit When All Traders Are Above Average. The Journal of Finance 53(6) : 1887 - 1934
12. Oeberst, A.; Goeckenjan, I. (2016). "When being wise after the event results in injustice: Evidence for hindsight bias in judges' negligence assessments". Psychology, Public Policy, And Law. 22 (3): 271-279. doi:10.1037/law0000091

13. Oehler, Andreas., Rummer, Marco., and Wendt, Stefan. 2008. Portfolio Selection of German Investors: On the Causes of Home-biased Investment Decisions. The Journal of Behavioral Finance 9: 149 - 162.

14. Parikh, Parag. 2011. Value Investing and Behavioral Finance. New Delhi : Tata Mcgraw Hill.

15. Payne, J. W., 1976, Task Complexity and Contingent Processing in Decision Making: An Informational Search and Protocol Analysis, Organizational Behavior and Human Performance 16, 366-387.

16. Payne, J. W., 2005, It is Whether You Win Or Lose: The Importance of the overall Probabilities of Winning Or Losing in Risky Choice, Journal of Risk and Uncertainty 30, 5-19.

17. Payne, J. W., J. R. Bettman, and D. A. Schkade, 1999, Measuring Constructed Preferences: Towards a Building Code, Journal of Risk and Uncertainty 19, 243-270.

18. Payne, J.W., Bettman, J. R. and E. J Johnson, 1992, Behavioral decision research: A constructive processing perspective, Annual Review of Psychology 43, 87-131.

19. Payne, J.W., Bettman, J. R. and E. J. Johnson, 1993, The adaptive decision maker, Cambridge University Press.

20. Liang, H., Yang, C., Zhang, R., \& Cai, C. (2017). Bounded rationality, anchoring-and-adjustment sentiment, and asset pricing. The North American Journal of Economics and Finance, 40, 85-102.

21. Baker, H. K., Filbeck, G., \& Ricciardi, V. (2017). How Behavioural Biases Affect Finance Professionals.

22. Chang, C. C., Chao, C. H., \& Yeh, J. H. (2016). The role of buy-side anchoring bias: Evidence from the real estate market. Pacific-Basin Finance Journal, 38, 34-58.

23. Gupta, Chabi. "Payment Banks and Demonetization", International Journal of Technical Research and Science, IJTRS-V1-I9-002, December 2016

24. Jones, P.and Roelofsma P. (2000) The potential for social contextual and group bias in team decision-making: biases, conditions and psychological mechanisms. Ergonomics, vol. 43, no. 8, pp. 1129-1152.

25. Kahneman, D. and Klein, G. (2010) Strategic decisions: When can you trust your gut? McKinsey Quarterly. http://www.mckinsey.com/insights/strategy/strategic_decisions_when_c an_you_trust_your_gut (2013-10-27) 